\title{
PLA2G4D Gene
}

National Cancer Institute

\section{Source}

National Cancer Institute. PLA2G4D Gene. NCI Thesaurus. Code C38595.

This gene is involved in the initiation of the inflammatory response. 